\title{
Detection of IL18 AND HSP70 LEVELS IN SERUM OF PATIENTS WITH ASTHMA
}

\author{
Zainab Nasser Nabat* Bareq A.ALateef Entsir marzoq \\ Babylon Technical institute/ AL-Furat AL Awsat Technical University, 51015 Babylon, \\ Iraq \\ *Corresponding Author: zainabnasser1989@gmail.com
}

\begin{abstract}
The current study included $5 \mathrm{ml}$ blood were collected from 100 patients with asthma and 100 controls. Who admitted to Hila General teaching hospital and margin hospital through the period from October 2017 to April 2018. The study deals with detection of cytokines concentration IL-18 showed increased at in concentration especially in age group (12-21 years) years and reached reach $314.777 \mathrm{pg} / \mathrm{ml}$ compared to control group. HSP70 showed increase in their concentrations in asthma patient than in controls especially at age group (12-21 years) years which reached $117 \mathrm{pg} / \mathrm{ml}$. The patient samples were applied to determine some parameters include ( $\mathrm{Hb}, \mathrm{RBC}$ count, WBC \& Eosinophil count). The results revealed that the mean $\mathrm{Hb}$ and $\mathrm{RBC}$ levels for asthmatic patients were lower than control $(8.5000 \pm 4.65855 \mathrm{~g} / \mathrm{dL}, 10.9979 \pm 4.09533 \mathrm{~g} / \mathrm{dL}$. $6.5000 \pm 4.07999310 \times 12 / 1, \quad 3.5183 \pm 6.0721610 \times 12 / L)$ respectively. In this study the patients suffered from Iron deficiency anemia and nutritional deficiency. While leukocyte and Eosinophile count values were higher than normal $(8.5000 \pm 4.65855 \mathrm{~g} / \mathrm{dl}$, $10.9979 \pm 4.09533 \mathrm{~g} / \mathrm{dl})$.
\end{abstract}

Keywords: Asthma, IL18, HSP70

DOI : doi.org/10.46617/icbe6006

\section{INTRODUCTION}

Asthma is endemic inflammatory sickness in the airway distinguish via changeful with recurrent signs, reflux of fickle airflow with bronchospasm (1). The prevalent signs comprise pant, bark, thorax narrowness, with mansion of respiration (2). Its diagnosis is commonly established on pattern of signs, reply to therapy over time and lung function testing (3). Asthma is a prevalent respiratory trouble worldwide, it is a heterogeneous sickness, genetic plus ecological agents may participate to its inception with continuance. Asthma is a major public health problem affecting millions person in the whole world (4) presently, asthma is increasingly prevalent worldwide due to air pollution and other environmental irritants. These environmental assertions are particularly clear in land development where manufacturing progresses rapidly (5) IL-18 is a unique cytokine that enhances innate immunity and immune response to Th1 and Th2. It was primarily report as an IFN-c stimulating factor generated through Kupffer cells, active macrophages, keratinocytes, intestinal epithelial cells, bone structures, and adrenal cortex (6)lately, although guides has been cumulative that the expression IL-18 increases in many signs of sensitivity (7) 
specially, it is required to distinguish regulatory $\mathrm{T}$ cells and defend against allergic asthma (8) IL-18 is a cytokine multivariate known to influence the immune response balance of Th1 / Th2, and is released from activated cells / macrophages, dendritic cells, and epithelial cells (9) IL-18 has been confirmed to cause asthma in various studies showing IFF-induced activity, its ability to raise serotonin IgE levels, and to promote the flow of iodine induced by allergens into the airway (10). HPS is a highly preserved proteins that is restricted to a variety of stress (eg, insinuation temperature) and pathogens (viral, bacterial, parasitic, ulcerative) or physiological (evolution agents, cell recognition, hormonal energizing) (11).There are six main Hsp families (eg, Hsp1, Hsp90, Hsp / Hsc70, Hsp60, Hsp40, and Hsp10-30) classified depending on their visible molecular molecules detected through the sodium dodecyl sulfate polyacrylamide (SDS-PAGE) electrolysis. (12).This indicate that Hsps may modify immune and inflammatory restraint and may be involved in causing and / or being dangerous signs and warning of a confirmed sickness involved asthma (13).

\section{Material and methods}

This study contains a total of 100 blood from patient's asthma and 100 control who admissible to Hila General teaching hospital and margin hospital through the time from October 2017 to April 2018. Blood samples were composed by vein puncture divided into two fractions, the first part were put in tube without anticoagulant. The serum was separated by centrifugation at about $3000 \mathrm{rpm}$ for 5 minutes. The serum levels of HSP70 and IL-18 were measured by an enzyme-related immunosorbent assay (ELISA), a technique called cytoskeletal immunohistochemistry using the Peprotech group (USA). The remaining of blood were put into tube with anticoagulant (EDTA) for haematological parameters, for determination of $\mathrm{Hb}$, PCV (RBCs. WBCs. eosinophil count).

\section{Results}

\section{Patients Demography}

This prospective study was carried out in two main hospitals at Al-Hilla General Teaching Hospital and, margin hospital from October 2017 to April 2018. A total of 100 blood from patient's asthma and 100 blood samples control were collected from patients have aged (2-71) years.

\section{Distribution of asthma According to Gender.}

This study was showing the prevalence of asthma among the male was $55(55 \%)$ compared to in females $45(45 \%)$ as it is clear in figure (1). 


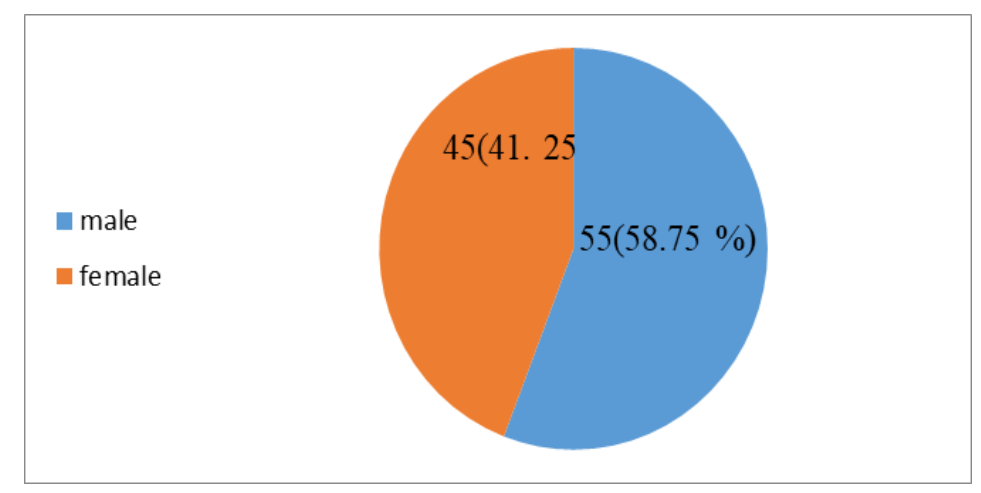

Figure (1) Distribution of asthma according to Gender.

\section{IL18}

The study shows high values of 1L-18 in patient's serum compared to healthy and high values in age class (2-21years) reach $314.777 \mathrm{pg} / \mathrm{ml}$ compared to in healthy and in same classes $12.000 \mathrm{pg} / \mathrm{ml}$. with a significant increase in mean values $(\mathrm{P}<0.05)$, between values, IL-18 in patients compared to healthy and also between the age group (2231 years) shows low values of IL-18 which reach $37.6667 \mathrm{pg} / \mathrm{ml}$ compared to in healthy, as in list (1) (Table 1).

Table (1): List (1) IL-18values in asthma patients and control

\begin{tabular}{|c|c|c|}
\hline \multirow{2}{*}{ Age group } & IL-18pg/ml & IL-18pg/ml \\
\cline { 2 - 3 } & Patient (M \pm S.D) & Control (M \pm S.D) \\
\hline $2-11$ & $210.6667 \pm 10.06645$ & $134.333 \pm 4.04145$ \\
\hline $12-21$ & $314.777 \pm 12.50333$ & $12.000 \pm 4.35890$ \\
\hline $22-31$ & $107.333 \pm 6.42910$ & $71.6667 \pm 6.65833$ \\
\hline $32-41$ & $94.6667 \pm 5.85947$ & $75.6667 \pm 5.13160$ \\
\hline $42-51$ & $37.6667 \pm 7.09460$ & $12.000 \pm 4.35890$ \\
\hline $52-61$ & $42.000 \pm 8.18535$ & $12.333 \pm 2.5161661$ \\
\hline $62-71$ & $59.6667 \pm 5.3322$ & $26.333 \pm 5.68624$ \\
\hline
\end{tabular}

LSD: 3.039.

\section{HSP70}

The study shows high values of HSP70 in patient's serum compared to healthy and high values in age class (12-21years) reach $117 \mathrm{pg} / \mathrm{ml}$ compared to in healthy and in same classes $114 \mathrm{pg} / \mathrm{ml}$. with a significant increase in mean values $(\mathrm{P}<0.05)$, between values, HSP70 in patients compared to healthy and also between the age group (3241years) shows low values of HSP70which reach $0.7133 \mathrm{pg} / \mathrm{ml}$ compared to in healthy, as in list (2) (Table 2). 
Table (2): List (2) HSP70 values in asthma patients and control

\begin{tabular}{|c|c|c|}
\hline \multirow{2}{*}{ Age group } & HSP70 pg/ml & HSP70 pg/ml \\
\cline { 2 - 3 } & Patient $(\mathbf{M} \pm$ S.D) & Control (M \pm S.D) \\
\hline $2-11$ & $2.3900 \pm 0.35679$ & $1.5333 \pm 0.37859$ \\
\hline $12-21$ & $117 \pm 67.50556$ & $114.000 \pm 12.16553$ \\
\hline $22-31$ & $12.6667 \pm 0.41633$ & $11.4500 \pm 0.39686$ \\
\hline $32-41$ & $0.7133 \pm 0.061101$ & $0.2033 \pm 0.2517$ \\
\hline $42-51$ & $7.6767 \pm 0.47606$ & $5.3267 \pm 0.23692$ \\
\hline $52-61$ & $12.6667 \pm 0.41633$ & $11.4500 \pm 0.39686$ \\
\hline $62-71$ & $29.333 \pm 4.50925$ & $20.9000 \pm 0.1000$ \\
\hline
\end{tabular}

\section{$\mathrm{LSD}=4.1$}

\section{Measures of some parameters in patient's asthma}

This study show that $(\mathrm{Hb}, \mathrm{RBC}$ count, levels for asthmatic patients were lower than control $\quad(8.5000 \pm 4.65855 \mathrm{~g} / \mathrm{dl}, \quad 3.5183 \pm 6.07216 \mathrm{~g} / \mathrm{d} 10.9979 \pm 4.0953310 / \mathrm{L}$, $6.5000 \pm 4.07999310 / \mathrm{L})$. While leucocytes and Eosinophil count vales were higher compared to control $(9.8638 \pm 2.8749410 \mathrm{~g} / \mathrm{L}, 0.302 \pm 36310 \mathrm{~g} / \mathrm{L}, 7.5000 \pm 4.0799910 \mathrm{~g} / \mathrm{L}$, $0.26 \pm 0.4410 \mathrm{~g} / \mathrm{L})$ respectively .

Table (3): Measure of some parameters in patients with asthma

\begin{tabular}{|c|c|c|}
\hline parameter & patients & Control group \\
\hline $\mathrm{Hb}(\mathrm{g} / \mathrm{dl})$ & $8.5000 \pm 4.65855$ & $10.9979 \pm 4.09533$ \\
\hline $\mathrm{RBCs}(1012 / \mathrm{L})$ & $3.5183 \pm 6.07216$ & $6.5000 \pm 4.079993$ \\
\hline Leucocytes(10g/L) & $9.8638 \pm 2.87494$ & $7.5000 \pm 4.07999$ \\
\hline Eosinophil(109/L) & $0.302 \pm 363$ & $0.26 \pm 0.44$ \\
\hline
\end{tabular}

\section{Discussion}

Bronchial asthma is single of the little persistent sickness in the advanced world that is widespread, despite a better understanding of its sickness and its therapy (14). Bronchial asthma is single of the extreme prevalent trouble in clinical medicine in both children and adults. This affects about 5\% of the adult population in the Western world, and it is more frequent in many developed countries. The backlash of the disease is necessary, and the pharmaceutical industry market has reached $\$ 5.5$ billion annually (15) The study show that asthma was prevalence in male at 47 (58.75\%) compared to female 33 (41.25 $\%$ ). A result was demonstrated prevalence of asthma in male compared to female because it appears that physiology of male and hyper activity when compared with female including age and smoking has a Has an association with in the occurrence of asthma. Smoking is a major risk factor for lung disease as confirmed by many studies (16). 


\section{Immunological Assay for asthma patients}

\section{Role of IL-18 in asthma patients}

In this study, shows high values of $1 \mathrm{~L}-18$ in patient's serum compared to healthy and high values in age class (2-21years) reach $314.777 \mathrm{pg} / \mathrm{ml}$ compared to in healthy and in same classes $12.000 \mathrm{pg} / \mathrm{ml}$. these study agreements with (5and 6)Who founds asthma prevalence in childhood in Iraq was $16.4 \%$ in children school-age. Increasing levels of IL-18 have been measured previously in the subjects of asthma in convergence. High levels of IL18 were found in patients with acute asthma (18). Its proinflammatory cytokines and as as an IFN$\gamma$-inducing factor and activation TH1 cell (19). Researches have shown recently that Interleukin -18 may possibility to act as a $\mathrm{TH} 2$ cell promoting factor in atopy. Interleukin -18 was found to have high concentrations in patients with asthma, allergic rhinitis, and atopic dermatitis. (20).IL-18 is excreted by total erythrocytes and was initially considered 18 (IFN- $\gamma$ inducing factor $(21,22)$ .(23) found that Interlukin -18 was elevated in sickness with persistent allergic rhinitis and rising levels of Interleukin -18 suggesting the word in the expression of persistent and exacerbated allergic inflammation. Interleukin -18 that play important role in immunological restrain and activity invert sickness for asthma exacerbation in mid and moderate (24).

\section{Role of HSP70 in asthma patients}

The study shows high values of HSP70 in patient's serum compared to healthy and high values in age class (12-21years) reach $117 \mathrm{pg} / \mathrm{ml}$ compared to in healthy and in same classes $114 \mathrm{pg} / \mathrm{ml}$. with a significant increase in mean values $(\mathrm{P}<0.05)$, between values, HSP70 in patients compared to healthy and also between the age group (32-41years) shows low values of HSP70which reach $0.7133 \mathrm{pg} / \mathrm{ml}$ compared to in healthy. HSP27 have been shown elevated concentration in patients with continuous obstructive pulmonary sickness. Its interleukin suggested that play important role in Bronchial asthma and ling disease $(25,26)$. Despite Hsp70 is known to play a role in the regulation of antigen peptides and in helping the synthesis of peptide type II, Hsp70 overexpression in APCs has a potential role for this protein in antigen and / or supply therapy, resulting in increased activity The APCs, which is essential for initiating and modifying the immune response to asthma in chronic asthma $(27,28)$.moreover ,Its interleukin has ability to control CD23 expression of THP1 cells and alveolar macrophages in Th2 environment. Thus, have important function in preserve continuous bronchitis in asthma (25). The results of the current study showed that asthmatic patients had anemia, as the concentration of both $\mathrm{H} \mathrm{B}$ and $\mathrm{RBC}$ were low compared with control Furthermore. We found in 
this study that WBC and eosinophils rates were higher than control group. As noted in various studies, the known risk factors for developing pulmonary disease include anemia, lower hemoglobin and a higher stable state of white blood cells (29). However decrease in hemoglobin concentration with elevation in white blood cells are common among asthma patients in compared with none asthma (30,31). Lastly, despite, the eosinophil cell play important function in defense against parasites and other pathogen, however, an increase in the number of Eosinophil is a factor in the diagnosis of asthma. (31).

\section{References}

1.M. FitzGerald, Chair; P. Barnes, N. Barnes, E. Bateman, A. Becker, J. DeJongste, J. R. Lemanske, P. O’Byrne, K. Ohta, S. Pedersen, E. Pizzichini, H. Reddel, S.Sullivan, S. Wenzel. Global Initiative for Asthma GINA updated 2010 Global Strategy for asthma management and prevention.

2-Martinez FD (2007). "Genes, environments, development and asthma: a reappraisal". European Respiratory Journal 29 (1): 179-84.

3-Akinbami, L.J. and Schoendorf,K.C. Trends in childhood asthma: Prevalence, Health careutilization and Mortality. Pediatrics. 2002; 110(2): 315-322.

4-Masoli, M. et al. (2004) the global burden of asthma: executive summary of the GINA Dissemination Committee report. Allergy 59, 469-478.

5-Lee SY, Chang YS, Cho SH. Allergic diseases and air pollution. Asia Pac Allergy 2013; 3:145-54.

6- Lachheb J, Chelb H, Ammar J, Hamzaoui K, Hamzaoui A.Promoter polymorphism of the IL-18 gene is associated with atopic asthma in Tunisian children. Int J Immunogenet. 2007;35: 63-8.

7-Sanders NL, Mishra A. Role of interleukin-18in the pathophysiology of allergic diseases. Cytokine Growth Factor Rev. 2016; 32: 31-9.

8-Koch KN, Hartung ML, Urban S, et al. Helicobacter urease-induced activation of the TLR2/NLRP3/IL18 axis protects against asthma. J Clin Invest. 2015; 125: 3297-302.

9-Sanders NL, Mishra A. Role of interleukin-18 in the pathophysiology of allergic diseases. Cytokine Growth Factor Rev. 2016; 32: 31-9.

10-Oda H, Kawayama T, Imaoka H, et al. Interleukin- 18 expression, CD8(+) T cells, and eosinophils in lungs of nonsmokers with fatal asthma. Ann Allergy Asthma Immunol. 2014; 112: 23-28 e1.

11-Ando M, Shima M. Serum interleukins 12 and 18 and immunoglobulin E concentrations and allergic symptoms in Japanese schoolchildren. J Investig Allergol Clin Immunol. 2007; 17: 14-9.

12-Hoshino T, Yagita H, Ortaldo JR, et al. In vivo administration of IL-18 can induce IgE production through Th2 cytokine induction and up-regulation of CD40 ligand (CD154) expression on CD4 T cells. Eur J Immunol 2000; 30:1998e2006.

13-Wong CK, Ho CY, Ko FW, et al. Proinflammatory cytokines (IL-17, IL-6, IL-18 and IL-12) and Th cytokines (IFN-gamma, IL-4, IL-10 and IL-13) in patients with allergic asthma. Clin Exp Immunol 2001; 125(2): $177 \mathrm{e} 83$.

14-Rovina N, Dima E, Gerassimou C, Kollintza A, et al. IL-18 in induced sputum and airway hyperresponsiveness in mild asthmatics: effect of smoking. Respir Med 2009; 103(12): 1919e25.

15-McKay A, Komai-Koma M, MacLeod KJ, et al. Interleukin-18 levels in induced sputum are reduced in asthmatic and normal smokers. Clin Exp Allergy 2004; 34:904e10.

16. Michaud S, Marin R, Tanguay RM: Regulation of heat shock gene induction and expression during Drosophila development. Cell Mol Life Sci 1997, 53:104-113.

17. Hightower LE: Heat shock, stress protein, chaperones, and proteotoxicity. Cell 1991, 66:191-197. 
18. Asea A, Kraeft SK, Kurt-Jones E, Stevenson MA, Chen LB, Finberg R, Koo GC, and Calderwood SK: HSP70 stimulates cytokine production through a CD14-dependent pathway, demonstrating its dual role as a chaperone and cytokine. Nat Med 2000, 6:435-442.

19. Singh-Jasuja H, Hilf N, Arnold-Schild D, Schild H: The role of heat shock proteins and their receptors in activation of immune system. Biol Chem 2001, 382:629-636.

20. Sato K, Torimoto Y, Tamura Y, Shindo M, Shinzaki H, Hirai K, Kohgo Y: Immunotherapy using heatshock protein preparations of leukemia cells after syngeneic bone marrow transplantation in mice. Blood 2001, 98:1852-1857.

21. Minowada G, Welch WJ: Clinical implications of the stress response. J Clin Invest 1995, 95:3-12.

22-Blachere NE, Srivastava PK: Heat shock protein-based cancer vaccines and related thoughts on immunogenicity of human tumors. Semin Cancer Biol 1995, 6:349-355.

23-National Heart, Lung, and Blood Institute, Section 2, Definition, Pathophysiology and Pathogenesis of Asthma, and Natural History of Asthma 2007, pp.1-58.

24-British Guideline on Management of Asthma, 1st published 2003, revised edition published 2009, pp.214.

25-Harkins MS, Moseley PL, Iwamoto GK. Regulation of CD23 in the chronic inflammatory response in asthma: a role for interferon-gamma and heat shock protein 70 in the TH2 environment. Ann Allergy Asthma Immunol 91:567-574, 2003.

26-Vignola AM, Chanez P, Polla BS, Vic P, Godard P, Bousquet J. Increased expression of heat shock protein 70 on airway cells in asthma and chronic bronchitis. Am J Respir Cell Mol Biol 13:683-691, 1995.

27-Tong W, Luo W. Heat shock proteins' mRNA expression in asthma. Respirology 5:227-230, 2000.

28-Bertorelli G, Bocchino V, Zhou X, Zanini A, Bernini MV, Damia R, Di Comite V, Grima P, Olivieri D. Heat-shock protein 70 upregulation is related to HLD-DR expression in bronchial asthma. Effects of inhaled glucocorticoids. Clin Exp Allergy 28:551-560, 1998.

29-Catro, O., Brambilla D.J. and ThoringtonB. 1994. The acute chest syndrome in sickle cell disease: Incidence and risk factors Blood, 84:643-649.

30-Jessica, H.B., Eric A.M., Robert C.S. and Michael R.D. 2006. Asthma is associated with acute chest syndrome and pain in children with sickle cell one mice. Blood 108:2923_2927

31-Zhao, MTakamura J., Yamaoka A., Odajima Y. and Likura Y. 2006. Altered eosinophil levels as a result of viral infection in asthma exacerbation in childhood J.Pediatr. J.Allergy.Immunol., 13(1):47-50 